Adina, J. (2020). Contemporary ceramics art and its transgressive side. 21st century: history and modernity of art. Collection of Scientific Articles. European Scientific e-Journal, 4 (4), 77-83. Hlučín-Bobrovníky: "Anisiia Tomanek" OSVČ.

Adina, J. (2020). Caracterul transgresiv al ceramicii artistice contemporane. 21st century: history and modernity of art. Collection of Scientific Articles. European Scientific e-Journal, 4 (4), 77-83. Hlučín-Bobrovníky: "Anisiia Tomanek" OSVČ.

DOI: $10.47451 / \operatorname{art} 2020-12-001$

EOI: $10.11244 / \operatorname{art} 2020-12-001$

The paper is published in Crossref, Internet Archive, Google Scholar, Academic Resource Index ResearchBib, JGate, ISI, CiteFactor, ICI, eLibrary databases.

(c) $\underset{\mathrm{EY}}{(7)}$

Jurca Adina

Doctor of Visual Arts

Senior Lecturer

Department of Ceramic-Glass

University of Art \& Design

Cluj-Napoca, Romania

E-mail: adina.jurca@uad.ro

\title{
Contemporary ceramics art and its transgressive side
}

Abstract:

This paper's author proposes a discussion on the ranking of ceramics as art, a few aspects in regards to Ceramic Art's inclusion in Contemporary Art context. The researcher is calling into question the shallow division between Decorative and Major Arts, a century after the distinction disappeared. Respectively, the art object made with ceramic material, in the general context of Contemporary Art and a few ways of manifestations of this art that leads toward permanent transgressive dimensions of artistic ceramic. The author concludes that Ceramic Art's Transgressive character emerges out of its operative mobility, moving from organic to geometric or from ornamental to sculptural, its late 1960s evolution being decisively situated towards an expressive original with technicalities and unprecedented formal mixtures.

Keywords:

ceramics, art, transgression, contemporary, major, decorative.

Adina Jurca

Doctor în Arte Vizuale

Lector Universitar Departamentul Ceramică-Sticlă Universitatea de Artă și Design Cluj-Napoca, România 
Email: adina.jurca@uad.ro

\section{Caracterul transgresiv al ceramicii artistice contemporane}

\section{Abstract:}

Acest articol îşi propune o discuție despre statutul ceramicii ca manifestare artistică, câteva aspecte ce privesc incluziunea artei ceramice în contextul artei contemporane. Vom pune sub semnul întrebării modul superficial de a separa încă artele - Arte Decorative şi Arte Majore, după un secol de la renunțarea acestor granițe. Respectiv, obiectul de artă realizat în material ceramic într-un context general al artei contemporane şi câteva moduri de manifestare ale acesteia ce conduc într-o permanentă dimensiune transgresivă ale artei ceramice. Autorul concluzionează că caracterul transgresiv al ceramicii se desprinde din mobilitatea operativă a acesteia, trecând de la organic la geometric sau de la ornamental la sculptural, evoluția sa de la sfârșitul anilor 1960 fiind poziționată decisiv spre un original expresiv, cu tehnicalități și amestecuri formale inedite.

\section{Cuvinte cheie:}

ceramică, artă, transgresiv, contemporan, majoră, decorativă.

\section{Introduction}

Without debating or (combating) any theory about what is being said regarding art at a theoretical level in a period is called by Post-Post Modern of the 21st Century, referring here to Contemporary Art specialist theorists and critics, I aim to bring in discussion a few aspects in regards to Ceramic Art's inclusion in Contemporary Art context.

This problematic approach comes out of my double role as an artist and teacher (in the Ceramics department), a professional combination which forces a type of awareness over the personal creation process within the workshop, as well as the duties of a teacher that must present the artistic creation phenomenon in general, as well as that of Ceramic Art.

Therefore, we will first bring into discussion Contemporary's Art problem, which over a century ago has become permissive of any kind of experiment (including famous ready-made examples which only by displaying an art object on a pedestal, a symbolic dimension was automatically attached to it, only by changing the angle of view by elevating it onto the pedestal. 
Going forward, the 'anything goes' concept was introduced, meaning that through the artists will, any object can become ART.

In this context, it is worth mentioning the segregation which placed Ceramic Art in the Minor or Applicable Arts area, although, there already is a precedent in the Art Nouveau period, in which the boundaries between Major and Minor Arts were abolished.

Therefore, we will conclude that the creation process can be realised without prejudice based on the nature of the material through which the artist chooses to express his vision, and this fact becomes more and more explicit and piercing following the unprecedented Post-modern Ceramics empowerment after the 1960s, when we witness and abundance in creative inventivity never seen before in Ceramics, capable of great development comparable to all the other art fields.

If the artistic object goes through a series of infinite transformations throughout history, we are fully aware that the same phenomenon takes place in a more accelerated rhythm in Contemporary Ceramics area, especially through its infinite unusual formation ways, in conceptual area, as well as artistic techniques, which through their very nature represent an element of expressivity that leads toward permanent transgressive dimensions.

These raised concerns aim towards eliminating confusion - without question, ceramic it is a material engaged into industrial production - and within it there is a well organised science, fundamental for precise serial and quantifying criteria which belong to the economy field - consumption blended with the industrial design object marketed demand but Ceramic Art object it is another cultural area.

Whereas, if we are only referring to the ceramic object and its way of being perceived and looked at throughout its millennial history, we cannot overlook its continuous reinvention.

During its transformative turmoil taking place in the second part of the 20th century, Ceramic Art object has pertinently demonstrated the overcoming of its own initial condition and through its merging towards resembling other artistic fields, moving towards a transdisciplinary territory of conceptual installation, mix-media, multimedia, etc.

Conclusively, this exact empowerment in Contemporary Ceramics field makes it surpass its own condition, placing it in an ascendant position which will continuously ensure inexhaustible creative potential in Contemporary Arts context. 
We can at the same time shed light into the formal justification, in itself transgressive, only through ignoring the thematic context in favour of its language expressive autonomy, arts purpose being that it asks itself and not the external reality.

If we take into consideration the historical models recovering means and placing them into a context mixed with the title 'original work', we would have to bring forward a canonical reasoning, meaning-a tendency that justifies and mediates 'the new' built on historical grounds.

Once the cultural clashes are eliminated, the boundaries all brought down or at least minimised, the art only needs to become reflexive, bearing down once again, over its own existential condition which is placed under question by Arthur Danto "it is perhaps unavoidable that it should turn into philosophy at last" (Danto, 2004).

If all the rules have been broken, and all restrictions have failed, thus art can do whatever it desires according to the saying 'anything goes' its practice is in the finishing stage.

Once we establish all the major aspects of the general transgressive phenomena, which is specific to modern art, stretched up its present manifestations, we can devote ourselves to a more or less elaborate presentation of the transgressive manifestation within the ceramic's arts field.

\section{2.}

Without doubt, the first transgressive characteristic we can identify as an inherent part of the ceramics material's 'behaviour' is its fluid character of blending-its relation between organic and inorganic, therefore providing with a various opportunity of formal expressions, from constructive severity, minimal-geometric, up to the most delicate and detailed natural shapes representation.

These extensive methods of the medium formalisation, made possible its operational transition from the functional object and/or ornamental to free-expressed sculptural and architectural monumental construct.

Based on these grounds, it has often been said that the solely use of clay as a means of expression, offers transgression opportunities - going beyond the limits between traditional and modern, functional - ornamental, free-expressed sculptural, monumental and ambiental.

The relevance of this fact comes out of the extremely extensive way of approaching a single ceramics specific manifestation segment - that of The POT-VASE, in itself 
becoming a representation of transgression in post-modern viewing, which slowly turns out into an exhibitor of various artistic scenarios, either enveloped in figurative 'trompe d'oeil' images, landscape mimetic, decorative mosaic, or as Amalgam Culture - 'funk super-object'.

If we would add to all these ceramics mimetic characteristic to simulate, faking tactile sensors, various man-made matters and materials, like stone, wood, leather, textiles, etc., displayed as stand-alone objectual instances, or organised as 'static nature of daily objects', we end up creating a more precise idea regarding ceramics wide transgressive potential.

Without doubt, as we mentioned previously, the transition from Pot-object to organic or figurative sculpture represented an important moment in transgression, from the perspective of traditional acceptance of ceramics, today being a common place of ceramic art manifestations out of all fields, from fine art to ambiental sculptural organisms, or ample monumental projects with an installation aspect.

As an immediate outcome of ceramics transgressive abilities, we stated above, art criticism, as well as curatorial organisms, began observing attentively contemporary ceramics evolution, seeking at the same time to shed light over important constructive and conceptual milestones in ceramics, for the educational benefit of the general public.

Following that, in 2004, at Tate Liverpool (UK), an exhibition entitled 'A Secret History of Clay' was organised, the express intent of this exhibition being that of demonstrating how painters like Gauguin and Picasso (we could also add Matisse, Degas, Chagall, Miro, Braque and Antonio Tapies), confirmed their art transgressive dimension, working in ceramics, thus showing how this 'secondary' ( to their main expressive background) practice, led them towards unusual original results.

Considerable are - as Amy Dickson (Gray, 2020) curator mentions in an interview held in 2010 - Gauguin's ceramic works which were 'utmost entirely unusual'. This example is demonstrative, most importantly because the minor and major categorial ranking in art is unwelcome, since the painters mentioned above, who worked with ceramic, transgressed the boundaries between craftsmanship and art, thus lessening the surroundings and prioritising their given artistic expressions.

Based on this issue, a movement called 'ANTICRAFT' was instituted in 1997, which comes in opposition to the elitist aesthetics in modern art, showing the decisive artistic value and not that of the material out of which the piece is manufactured a work of art. 
Sadly, the theoretical level issue remained unresolved; at a theoretical level, the artificial problematization of this hierarchy takes its toll over perceiving ceramics art in art exhibitions.

It is obvious debates tensions still happen in an unusual manner, when it comes to separating art from craftsmanship and the ceramic's objective position, particularly its metaphoric and semiotic capacity, beyond referring to a given capacity which intimately ties it to a utilitarian ritual.

As we mentioned earlier, ceramics evolved starting with the early 1950s, without changing its historical domestic functionality course, towards a domestic transgression, first evolving towards a refined aesthetic presented in the oriental extreme aesthetics, in which its functional component makes room in favour of the contemplative nature of the object.

This was appropriately presented in an exhibition organised at the Royal Academy of Arts, entitled "Modern British Sculpture" (Curtis \& Keith, 2011), curated by Dr Penelope Curtis - Director of Tate Britain, along with the sculptor Keith Wilson, who also included Sung Dynasty plates within the exhibition and pieces created by Bernard Leach and William Staite Murray.

Ceramics and Sculpture connection was also addressed in the early 1990s, through an exhibition entitled 'The raw and the cooked: New York in Britain', whose purpose was presenting an environment that was bound to push further away from the domestic area, claiming itself as an intellectual and cultural art object.

Through this exhibition, once again, the curators confirm the intention of changing ceramics perception, convincingly supported by the modernist label of an utilitarian art, decorative in the best scenario, also displaying among the ceramic works of a few wellrenowned ceramic artists, clay sculptures in honour of Tony Cragg, Thomas Shuttle or Arman, whose expressive load and plastic valence prove ceramics transgressive force, which once again proves its migration in sculptural field.

Since we already mentioned the artistic changing the common Bowl has suffered, developing in collaboration with the painting and sculpture, as well engaging in monumental size projects, Clare Twomey's impressive pile of broken pots 'exhibit' stands out in the entrance at the exhibition Possibilities and Losses: Transition in Clay, held at the Middlesbrough Institute of Modern Art.

Surely, this piece inclines towards post-industrial - which is more extensively analysed in Postmodern Ceramics by Mark Del Vecchio (Del Vecchio, 2001), and as it 
follows, brings light over the post-industrial deterioration in ceramics industry, in the exhibition climate, it can be perceived as a monumental object, built based on the multiple rules which creates a tension between something very familiar (a mug that can be held) and the extension of this intimate dialogue between man and object at a gigantic scale that conjures a deconstruction of a near-time memory.

Furthermore, the idea of making a monument out of broken objects, which always had the purpose of memory, for eternity, but the building elements prove its time-lasting weakness, opens a window of combinations in which conceptual elements overpower those formal-aesthetics.

Thus, after contemplating over the limitless art examples which can stand as arguments towards ceramics transgressive propensity, we cannot ignore last hour transgressive instances, manifested in the last years through International Ceramics Biennale, like the one in Guanggiu Ju, Korea, which dedicated itself on approaching mix-media and multimedia in ceramics.

\section{Conclusion}

Therefore, Ceramic Art's Transgressive character emerges out of its operative mobility, moving from organic to geometric or from ornamental to sculptural, its late 1960s evolution being decisively situated towards an expressive original with technicalities and unprecedented formal mixtures.

Thus, this speech raises awareness over always surprising formation forces and reinventions, a fact should lead to a different perception of this art, which carries in its essence a variety of human creative sensibility and claims its rightful place in Contemporary Art.

\section{References:}

Curtis, P., Keith, W. (2011). Royal Academy Books. Danto, A. (2004). The Philosophical Disenfranchisement of Art. USA, Columbia: University Press.

Del Vecchio, M. (2001). Postmodern Ceramics. London: Thames \& Hudson.

Gray, L. (2020, March 12). Museums and the Interstices of Domestic Life': Re-articulating Domestic Space in Contemporary Ceramics Practice. Retrieved April 25, 2020 from http://www.interpretingceramics.com/issue013/articles/03.htm/12/03/2020 
Kadhim, R.S. (2019). Visual Discourse in Postmodern Ceramics. Revista de Cientias Humanas y Sociales, 20, 2899-2921.

Milevin, E. (2018). Movers \& Shokers in American Ceramics. Defining Twentieth Century. Ceramic. Monthly Handbook. 